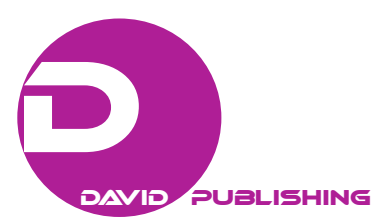

\title{
A Growth of the Urban Public Space in the British New England
}

\author{
WANG Wei-hong \\ Northeast Normal University, Changchun, Jilin, China
}

\begin{abstract}
Colonial New England urban economy was growing prosperity from 17th century to 18th century, all kinds of urban public space was increasing in number, the increasingly rich on the function, which became important place for colonial population aggregation and consumption. What people from different place come into the big and small cafes, taverns, shops, and the most important Town House took sharing information, emotional communication, business negotiation and other matters, which reflecting the colonial town's economic and social progress.
\end{abstract}

Keywords: New England colonies, public space, social progress

17-18th century, Colonial New England economy was booming, at the same time, the public space in the towns was increasing in number, the increasingly rich on the function, became an important place for daily consumption and urban population aggregation, urban residents in which information sharing, emotional communication, business negotiation and other matters. In New England towns, cafes, taverns, shops, and the most important Town House increasing, all of these became the most important public space for colony society. This change reflected the New England colonies of urbanization progress and the changes of the consumer society. Research about this problem, the domestic academic circles no one study on this question. And American academic research on this problem is just beginning (Martha, 2001). About the growth of the urban public space and colonial social change deserves further study.

Town House was the most important public space in the Colonial towns. In general, theater played an important role in the city's public life in the 17th and 18th centuries Atlantic world, but New England Puritan had a thought the theater violated the Puritan doctrine, could cause people despise of religion, also could increase the tendency of people immoral and not religious, banned any professional theatrical performances in the colonies (Hoover, 1984). That is to say, in the New England colonies, give play to the role of public space must be to other institutions or facilities. And in the public space, the most important thing was Town House of each town. In Boston, Salem, Plymouth built Town House. As early as 1658, Boston built the Town House, after because a fire destroyed it, and rebuilt it in 1713. The purpose to build Town House of each town, aims at providing a secular place for government and businessmen, and judicial court activities. In many cases, historian often regarded Town House as a meeting place whose function appears to be principally as a local secular affairs and religious affairs (McNamara, 2001). But, in fact, Town House had political, legal, economic and social function. Which was the political, commercial and cultural center of New England, here brings together governments, courts, market and militia. Town House design itself was integrated the function of these considerations. For example, in Boston, the first floor of the Town House, its design was open to be a marketing center, everyone can be trade here. At the same time, it was an important part of the information

WANG Wei-hong, Ph.D. Candidate, School of History and Culture, Northeast Normal University. 
market, from different parts of the colonists gathered here, to share their market or business information from all over the world. And, around the town was covered with large and small stores, bookstores and printing, etc. In the 1730s, in addition to the coastal port cities and towns, some of the inland towns in New England were established Town House, such as in Ipswich, Springfield, etc., these local Town House design was almost same with Boston, on the first floor were open design, which was the important public space for the local residents (McNamara, 2001, p. 134). But, by contrast, in general, the coastal port's Town House function was more active and complex than the inland towns. This was mainly due to the area between the differences in the complexity of the commercial economy.

In the 1740s, increasingly cafes became the new public space. At the end of the 17th century and the early 18th century, cafes like walking street, assembly hall, were very popular in London, as a new public space provided a new convenient place for businessman sharing information. When London businessmen increasingly dependent on public space to collect the latest market and business information at the mid-17th century. It was influenced by the British, businessmen were starting to invest cafes in New England, growing number of cafes, from the coastal ports to the inland towns were quite popular. On the one hand, cafes became a good place for people to taste coffee and leisure or entertainment; On the other hand, which became a commercial transactions center, information communication, and an important part in political exchanges. For example a Boston man, often go to the British Coffee House to meet with businessmen and various professionals, organizations and discuss business affairs of this town, or a general communication and jokingly. To some extent, the cafe became his daily or at least his office conference room (Hunter, 2001, p. 144). Even cafe as a new ideal place for all kinds of people showed their new fashion. Therefore, when a person want to know the world latest fashionable clothing or consumer tastes, cafe was the best choice, cafe became an epitome of imitation the Atlantic world newest fashion. In Boston, The Crown Coffee House at Long Wharf often held all kinds of auctions and exhibition all sorts of adornment, painting for higher social class (Hunter, 2001, p. 89). Learning London larger cafe management pattern, Colonial New England cafes boss earned extra income through the indoor display or performance chess, jokes, or a few small games.

Taverns had become a mass consumption and often go to places of entertainment. The church of the New England colonies has always been very alert to drinking, but from all kinds of the church's sermon was not hard to find, the tavern consumption become an unstoppable tide of mass consumption. Massachusetts famous priest Cotton Mather said: "rum was a greater disaster than a French invasion" (Miller, 1953, p. 306). In addition, it was clearly against the growing tavern consumption in a sermon of 1726. Because, it was not only the ordinary people, but also many religious instructors were addicted to. So, the sermon taught the people: can't afford to waste a lot of time in the tavern, and should only after a hard day, at night can relax appropriately. And tavern consumption should be control the most appropriate or the lowest proportion, it is really waste money for tavern, because there are a lot of poor people need help. As a result, the sermon was a warning to the crowd: don't throw a lot of time and money in the pleasures of $\sin .{ }^{1}$ However, the consumption habits once formed seems unlikely ever to be reversed.

In addition to the coffee house, with the growth in wealth in the New England towns, many people began to pursue a variety of entertainment to enjoy, as a result, some new quantity public space rapid growth with the entertainment, including all kinds of hunting, fishing, sports, horse racing and other sports venues, along with a

\footnotetext{
${ }^{1}$ Early American Imprints, Series 1, no. 2780: Thomas Foxcroft, “A Serious Address to those Who Unnecessarily Frequent the Tavern", Boston, 1726, pp. 1, 2, 4, 5.
} 
variety of concert hall, dance hall, restaurant and outdoor walking space, etc., all of that gradually became new ways of entertainment and leisure for urban population. Among them, especially dance very popular and became an important form of social performance in the New England polite and merchant class. In 1744, Alexander Hamilton, a Maryland gentleman during his stay in Boston, expressed admiration for here. He noted that "the gentleman and ladys meeting almost every week att consorts of musick and balls" (Hunter, 2001, pp. $88,109)$. People also promote each other business communication and information sharing by this way. In addition, all sorts of gentlemen's clubs and public facilities such as library also increase gradually sponsored by some traders (Beranek, 2007, pp. 70-71). All of public space promoted friendship between personal or business contact, and which was reflecting the progress of social material life and spiritual life of Colonial New England towns.

\section{References}

Beranek, C. M. (2007). Merchants, Gentry, Farmers, and Brokers: Archaeology of the complex identities of the Tyng family of Dunstable, Massachusetts, in the Eighteenth Century (Ph. D. diss., University of Pennsylvania).

Hoover, C. A. (1984). Music in Eighteenth-Century American Theater. American Music, 2(4), 8.

Hunter, P. W. (2001). Purchasing identity in the Atlantic World: Massachusetts Merchants, 1670-1780. New York: Cornell University Press.

Martha, J. M. (2001). In the Face of the Court: Law, commerce, and the transformation of public space in Boston, 1650-1770. Winterthur Portfolio, 36(2/3), 125-139.

McNamara, M. J. (2001). In the face of the court: Law, commerce, and the transformation of public space in Boston, 1650-1770. Winterthur Portfolio, 36(2/3), 125-126.

Miller, P. (1953). The New England Mind: From colony to province. Cambridge: Harvard University Press. 